\title{
e-Promotion; A Revolution in Technical Education Evolution
}

\author{
Mahajan P. T. \\ Research Scholar \\ Registrar, R. C. Patel Institute of Technology, Shirpur, Maharashtra, India \\ E-mail: registrar.rcpit@gmail.com, registrar@rcpit.ac.in \\ Mobile: +91 9822190091
}

\author{
Golahit S. B. \\ Research Guide \\ Head of Department, Department of Economics, \\ KVPS's S.P.D.M. College, \\ Shirpur, Maharashtra, India
}

\begin{abstract}
Despite of increasing pressure related to enrollment in Technical Education, some Institutes of Technical Education, successfully have taken on a corporate mentality to attract and retain highquality students through their e-Promotion. Successful branding and marketing strategies have become most important for the Institutes of Technical Education to appeal to a growing and diversified student and to differentiate from competitors. Effective branding can be helpful in increasing enrollment and in developing relationships and bonding. This article explores internet based promotions that Technical Education institutes have focused on branding and marketing initiatives and its influence on the students in selecting institute. It also focuses on effectiveness of internet based promotions. The research study showed that Institute Website and Social Networking are the most influential promotion tools for making their decision of selection than the other traditional promotion tools. In addition, these tools are reported to be very powerful and effective in making satisfaction of decision of selection which is highly associated with such a promotion tools. More surprisingly, it is found to be productive in the rural area. This article presents an adaptation of established qualitative research methods by a survey (through a structured questionnaire) of students who are presently enrolled (Current-students) and those who have completed their study (Post-students) belonging to the institutes offering Technical Education situated in Khandesh region of India and affiliated to the North Maharashtra University, Jalgaon. The survey is delimited to the
\end{abstract}


enrollments of Technical Education belonging to North Maharashtra University, Jalgaon and located in Khandesh region of India.

Keywords Enrollments, e-Promotion, Promotion Mix, Satisfaction, Technical Education.

\section{INTRODUCTION}

The Internet has had a transformative impact on the way that knowledge is generated, shared and consumed. Use of Internet Marketing techniques in Technical Education to attract and engage students is relatively new. Most of research revealed that students are seeking information on college web sites. In recent years, branding and marketing in Technical Education have significantly changed in in terms of internet based promotion (e-Promotion), with an increased external engagement and communication. There are a large number of students who are considering attending college, and colleges need to market themselves effectively to attract the students they most want [1]. Because of the instant access to important information through Internet search engines and a prospective student that frequently uses the Internet, colleges are viewed by students online and increasingly less verbal or face-to-face interaction takes place. These anonymous potential students may proceed through most of the admissions steps from a distance and many even prefer to apply electronically and avoid direct interaction with admissions staff [2]. For higher education institutions relationship marketing involves building and maintaining a relationship of value exchanges between the institution and the three main customer groups: alumni, current students and future students. The quality of these relationships is positively related to the customers' long-term loyalty [3].

Print media has start losing young readers. As per the study 18 percent of 15-20 age group, 12 percent of 20-30 age group and 8 percent of 30-40 age group readers have reduced their interest to read print newspapers, they prefer to read online newspapers [4]. The Internet and Mobile Association of India and IMRB report said "almost half the urban social media users hail from the 
top four metros". The use of social media in rural India has grown 100 per cent (doubled) in the past year with 25 million people using the Internet to access Twitter and Facebook, According to a report, in India, Facebook emerged the leading social media website with 96 per cent of urban users accessing it, followed by Google Plus (61\%), Twitter (43\%) and LinkedIn (24\%). The largest segment of users was college-going students (34\%), followed by young men (27\%), the report said. Schoolchildren constitute $12 \%[5]$.

\section{II. e-PROMOTION}

Basic principles of e-Promotion or Internet Marketing which are discussed on various internet blogs are convenience, reach, cost personalization, relationship and social [6] [7] [8]. Convenience: Students or related service receivers can browse institute at any time and place when it is convenient for them. Reach: Institute can promote their services in any part of the country without setting up local outlets, widening their target market. Cost: Marketing on the Internet costs less than marketing through a physical marketing. Cost on printing is very much reduced. Personalization: Institute can track potential students by creating blogs and fulfilling their person needs. Relationship \& Investment: It provides an important platform for building relationships with students at all levels. When a student is enrolled, Institute can develop relationship by engaging him on web and inviting him to submit reviews on Institute service. Social Engagement: Engagement or Investment is defined by reference [9] as the time, energy, and other resources an organization is willing to devote to build a relationship. Social responsibility and community involvement, or building communal relationships, are considered indicators of organizational investment [10].

\section{Social Networking}

Social networking services facilitate the development of online social networks by connecting a user's profile with those of other individuals and/or groups [11]. Research provides 
evidence that an increasing number of organizations are already engaging with social media as part of their marketing strategy [12] [13]. A study reveals that India has recorded world's largest growth in terms of social media users in 2013 [14]. Engaging with social media as a higher education marketing tool is an attractive proposition, because of positive past experience in the business sector on the effects of social media marketing and the high adoption rates of social media by the younger generation [15]. Improved communications, customer engagement and increasing brand loyalty have been identified as outcomes of this form of marketing. Social media is a relatively new but fastgrowing category of online interactive applications. These applications are based on user-generated content rather than supplier-generated content allowing peer-to-peer communication and user participation [16] [17]. The term "social media" is widely used nowadays. The first time it appeared was in 2004, after LinkedIn created its social media networking application. Reference [18] defined the social media application as an online technology tool to allow people to communicate easily, utilizing the internet to share and discuss information. According to [19], social media is defined best in the context of the previous media paradigm. Traditional media such as television, newspaper, radio and magazines are one-way, static broadcasting technologies. Having a Facebook page has become a virtual prerequisite for many companies [20]. Internet marketing enables institutes to take advantage of the growing importance of social media. Institute can take advantage of this type of influence by incorporating social networking tools in Institute's promotional campaigns.

\section{Website}

A set of interconnected webpages, usually including a homepage, generally located on the same server, and prepared and maintained as a collection of information by a person, group or organization [21]. Websites are an excellent avenue for building and maintaining relationships between organizations and their publics. There are several characteristics of websites, such as 
content richness, design flexibility, interactivity. Both public relations scholars and practitioners agree that organizational websites play an important role in building and maintaining relationships with important publics [22] [23]. Websites enjoy great interest especially due to the fact that, they serve as one of the most common sources of gaining information. In the professional world, there is a sense that corporate public relations websites influence a public's perceptions of an organization, and loyalty towards it. The matter of improving the quality of websites and searching for suitable methods for assessment is dealt by [24]. Reference [25] focus on defining framework for a website evaluation. Reference [26] claim that providing a positive experience on the organization's website is crucial to maintaining a good relationship with publics, increasing reputation and customer loyalty and ultimately surviving as a business. An institute's web presence is extremely important because visiting the website first is found to be a precursor to visiting the campus.

\section{Students Satisfaction}

Customer satisfaction may be perceived as a summary psychological state or a subjective summary judgment based on the customer's experiences compared with expectations. The concept has been defined in various ways, such as "an overall feeling, or attitude, a person has about a product after it has been purchased" [27], or as "a judgment that a product or service feature, or the product or service itself, provided (or is providing) a pleasurable level of consumption-related fulfillment, including levels of under- or over fulfillment" [28]. An adaptation of the definition regarding students has been proposed by [29], who state that student satisfaction is an attitude that results from the evaluation of their experience with the education service received. Student satisfaction is supposed to be positively related to the students' perceptions of the reputation of the educational institution [30].

\section{Conceptual framework of e-Promotion and Satisfaction}


(Figure 1: Conceptual framework adopted from Literature Review)

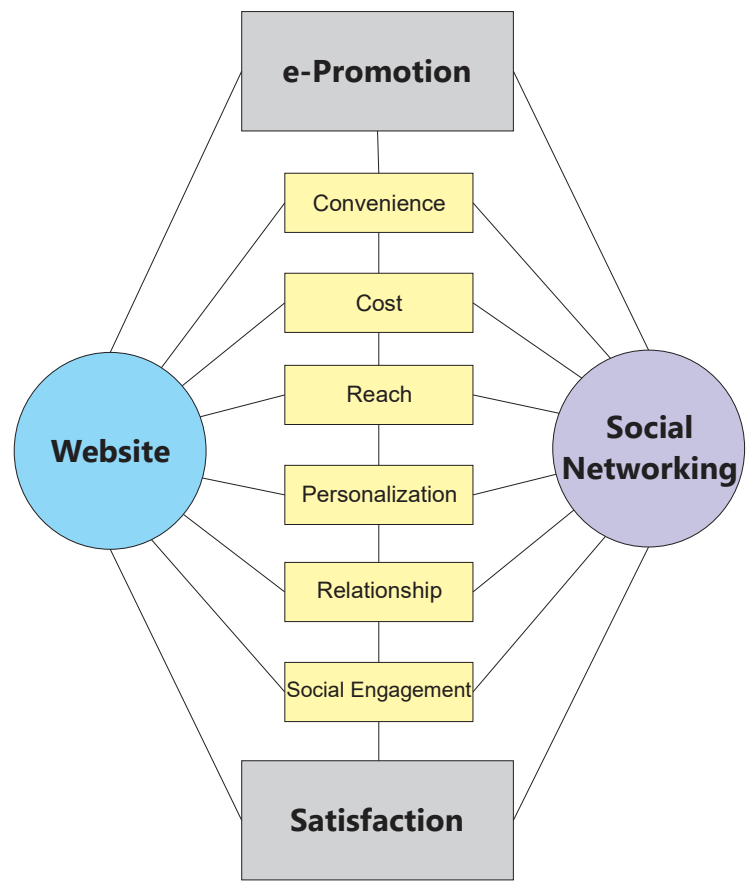

\section{Hypothesis}

H1 : e-Promotion Mix performs better than the other traditional promotion mix.

H2 : e-Promotion is highly associated with the satisfaction of students' in selecting institute of Technical Education of their choice.

\section{RESEARCH METHODOLOY}

The objective of this research was to find out e-promotion's influence in selection of Technical Education institute and its effectiveness in terms of student's satisfaction on the decision of selection. A qualitative research through a survey which comprised of a structured questionnaire was conducted through e-mail sent to the current-students enrolled and passed-out students (alumni) belonging to the technical institutes affiliated to North Maharashtra University. Sample size (n) was calculated at 95\% Confidence Level for which Standard Normal Variate (Z) is 1.96 \& at Standard 
Error (e) of 0.03 by $n=Z^{2} \frac{(p)(1-p)}{e^{2}}$; where $\mathrm{n}=$ Sample Size to be used for this study, $\mathrm{N}=$ unknown population, $\mathrm{p}=$ Estimated Portion of Population N. For $\mathrm{p}=90 \%$, ' $\mathrm{n}$ ' comes out to be 553. However, sample size of 663 was selected by quota sampling from the students (belonging to engineering, pharmacy and management programs) and based on their native place and gender. There were 455 male and 208 female students (Current as well Post-students) of which 491, $113 \& 59$ belonged to Engineering, Pharmacy and Management program. 162 students belonged to District Place as their native place while 283 and 218 belonged to Taluka and Village Place respectively. The questionnaire comprised of structured and closed ended questions measuring influence of Promotion Mix adopted by the institutes on the selection of Technical Institute on a scale ranging from 0 to 5 (where value zero, was no influence at all and value five, was most influence). To test H2, responses were also collected on satisfaction level on their decision of selection of an institute.

\section{DATA INTERPRETATION AND FINDINGS}

\section{Influence of e-Promotion Mix}

Bar-chart 1 shows that mean of influences of Website, Social networking and Publicity is higher than the other traditional promotion mix. The influencer 'Publicity' is also higher due the fact that publicity can be made through Website as well as Social Networking also. Thus, it is proved that e-Promotion's influence is better than the other traditional promotion mix. H1 is accepted. 


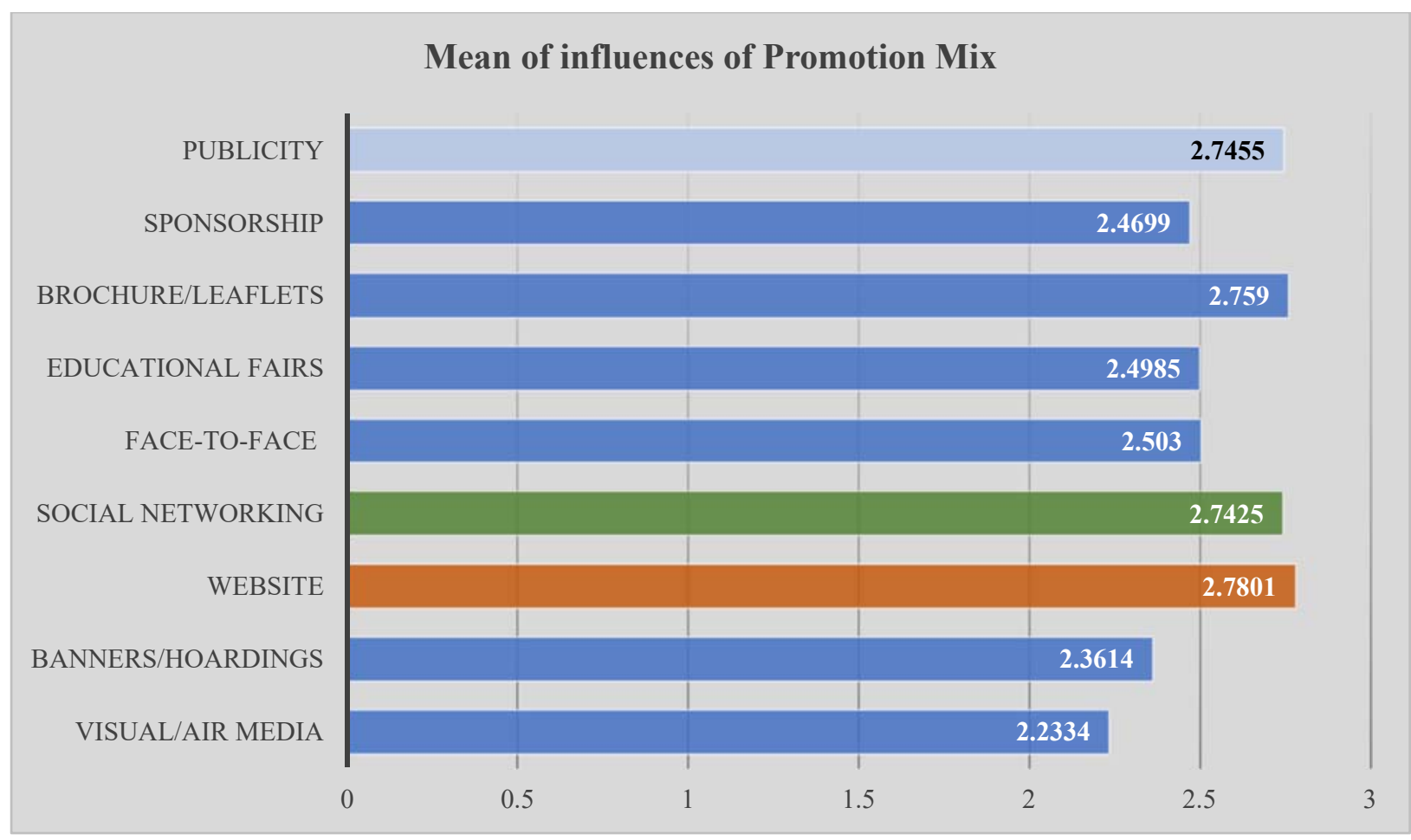

(Bar-chart 1: Mean of influences of Promotion Mix on Selecting Technical Education Institute)

\section{e-Promotion Vs Satisfaction of Selection of TE Institute}

Table 1 shows that the mean of responses- 'Completely Satisfied' on the decision of selection of TE Institute, which was influenced by different promotion mix.

\begin{tabular}{|c|c|c|c|c|c|c|c|c|c|c|}
\hline & & $\begin{array}{c}\text { Visual/ } \\
\text { Air } \\
\text { Media }\end{array}$ & $\begin{array}{c}\text { Banners/ } \\
\text { Hoardings }\end{array}$ & Website & $\begin{array}{c}\text { Social } \\
\text { Networking }\end{array}$ & $\begin{array}{c}\text { Face- } \\
\text { to- } \\
\text { Face }\end{array}$ & $\begin{array}{c}\text { Educational } \\
\text { Fairs }\end{array}$ & $\begin{array}{c}\text { Brochure/ } \\
\text { Leaflets }\end{array}$ & $\begin{array}{l}\text { Sponsor- } \\
\text { ship }\end{array}$ & Publicity \\
\hline \multicolumn{2}{|c|}{$\begin{array}{c}\text { Mean of } \\
\text { 'Completely } \\
\text { Satisfied' }\end{array}$} & 2.42 & 2.53 & 3.04 & 3.05 & 2.78 & 2.86 & 3.06 & 2.81 & 3.03 \\
\hline \multirow{2}{*}{$\begin{array}{l}\text { General } \\
\text { Linear } \\
\text { Model by } \\
\text { MANOVA }\end{array}$} & $\begin{array}{c}\text { F- } \\
\text { Value }\end{array}$ & 5.13 & 7 & 11.93 & 15.54 & 9.74 & 15.57 & 13.47 & 12.96 & 13.09 \\
\hline & $\begin{array}{c}\text { p- } \\
\text { Value }\end{array}$ & 0.002 & 0.000 & 0.000 & 0.000 & 0.000 & 0.000 & 0.000 & 0.000 & 0.000 \\
\hline
\end{tabular}




\begin{tabular}{|c|c|c|c|c|c|}
\hline \multicolumn{6}{|c|}{$\begin{array}{l}\text { MANOVA for Satisfaction Level } \\
\qquad \mathrm{s}=3 \quad \mathrm{~m}=2.5 \quad \mathrm{n}=325.0\end{array}$} \\
\hline \multicolumn{3}{|l|}{ Test } & \multicolumn{3}{|l|}{ DF } \\
\hline Criterion & Statistic & Approx F & Num & Denom & $\mathrm{P}$ \\
\hline Wilks' & 0.88636 & 2.975 & 27 & 1904 & 0.000 \\
\hline Lawley-Hotelling & 0.12512 & 3.015 & 27 & 1952 & 0.000 \\
\hline Pillai's & 0.11640 & 2.933 & 27 & 1962 & 0.000 \\
\hline Roy's & 0.09492 & & & & \\
\hline (Obtained by Stati & al Softwar & ТАВ 17) & & & \\
\hline
\end{tabular}

(Table 1: Promotion Mix Vs Satisfaction on Selecting Technical Education Institute)

F-value for Website, Social Networking and Publicity are 11.93, 15.54 and 13.09 which are significant at 0.05 . This also reveals that Website $($ Mean=3.04) and Social Networking $($ Mean=3.05) are highly associated with the satisfaction of students' in selecting institute of Technical Education of their choice than the other promotion mix. Hence, $\mathrm{H} 2$ is accepted.

\section{PRACTICAL IMPLICATIONS}

Promotion of an institute is important aspect in today's competitive age and where the enrollments in Technical Education is a big problem. e-Promotion is gaining importance due to empowering effect, elimination of geographic barriers, target reaching, immediate results, cost effective, reaching wider or international auditory, measurable result, can be personalized, relationship build, 24 hours / seven days' availability. Its' is the easiest and simplest way for developing brand image at no cost (or low cost). Institutes, which are unable to reach rural part or tribal part can easily move with e-Promotion. Rural part of India comprises almost $70 \%$ of the population. Targeting this sector by e-Promotion strategies will increase the enrollments.

\section{CONCLUSION}

In the era of globalization internet plays a vital role in all spheres of life and industries. Whether you sell products online or not, e-Promotion is essential for virtually every business. 
Internet users in India growing very fast in India, as per the latest report of Internet and Mobile Association of India, India will overtake the US (as the second largest base). As per the research by US based research firm eMarketer (2014), India will overtake the US as the second largest market for Smartphone in the world by 2016. With the help of Internet on mobile phones (Smartphone), online news or information can be read anytime and anywhere. This is the biggest opportunities for the Institutes offering Technical Education in India. Creating an e-presence is much more than creating a small website with contact details. An e-presence is the image of an institute that will be created in the eyes of every visitor whenever they access website or come across with any social networking links on the Internet while browsing. These foot prints play a very important role in the virtual brand image creation, attracting students and developing relationship with the community. 


\section{REFERENCES}

12010 E-recruiting practices and trends at four-year and two year institutions. (2010). Retrieved September 26, 2010 from www.noellevitz.com/E-ExpectationsSeries

2 Bell, A. D. (2009). College knowledge of 9th and 11th grade students: Variation by school and state context. The Journal of Higher Education, 80(6), 663-685.

3 McAlexander, J.H., \& Koenig, H.F. (2001). University Experiences, the Student-College Relationship, and Alumni Support. Journal of Marketing for Higher Education, 10(3), 21-43.

4 Tewari P (2016). Is Print Readers Declining? A Survey of Indian Online Newspaper Readers. Socialomics 5:177. doi:10.4172/2167-0358.1000177

5 Bhargava, Yuthika (2015). Use of social media doubles in rural India. The Hindu. http://www.thehindu.com/sci-tech/technology/internet/social-media-use-doubles-in-ruralindia/article7334735.ece

$6 \mathrm{https} / / / \mathrm{www}$. doz.com. http://www.doz.com/marketing-resources/top-5-benefits-using-online-marketingcampaign. Retrived 10/14/2014 by John DOZ

$7 \mathrm{http} / / /$ www.sas-itc.com/node/40 by Sheron Jackson on 01/02/2015

8 https://gescis.com/6-main-benefits-of-internet-marketing/

9 Ledingham, J. A. and Bruning, S. D. (1998). Relationship management in public relations: Dimensions of an organization-public relationship. Public Relations Review, 24(1), 55-65.

10 Ledingham, J. A. (2000). Guidelines to building and maintaining strong organization-public relationship. Public Relations Quarterly, 45(3), 44-46.

11 Boyd, d.m.; Ellison, N.B. (2007). "Social Network Sites: Definition, History, and Scholarship". Journal of computer-mediated communication. 13 (1): 210-230. doi:10.1111/j.1083-6101.2007.00393.x.

12 Barnes, N.G., \& Mattson, E. (2009a). Social media and college admissions: The first longitudinal study. Center for Marketing Research, University of Massachusetts Dartmouth. Retrieved February 2, 2010, from http://www.umassd.edu/cmr/studiesresearch/mediaandadmissions.pdf

13 Barnes, N.G., \& Mattson, E. (2009b). Social media in the 2009 Inc. 500: New tools \& new trends. Center for Marketing Research, University of Massachusetts Dartmouth. Retrieved February 2, 2010, from http://www.umassd.edu/cmr/studiesresearch/socialmedia2009.pdf

14 IANS, 2014. India records highest social networking growth Rate: Study. news.biharprabha.com. IANS. 26 July 2014. Retrieved 26 July 2014.

15 Boyd, D. (2008). Why youth (heart) social network sites: The role of networked publics. In D. Buckingham, Youth, Identity, and Digital Media (pp. 119-142). Cambridge: The MIT Press

16 Nambisan, S., \& Nambisan, P. (2008). How to profit from a better virtual customer environment. MIT Sloan management review, 49(3), 53.

17 Shankar, V., \& Malthouse, E.C. (2009). A peek into the future of interactive marketing. Journal of Interactive Marketing, 23(1), 1-3.

18 B\&C, what's this stuff called "social media," Benefits \& Compensation Digest. Vol. 47, no.3, p.10, March 2010.

19 Zarrella, D., "The social media marketing book”, Canada, O'Reilly Media, Inc,p. 3, 2010.

20 Kotler, Philip and Keller Kevin (2012). Marketing Management. Pearson Education, Inc., publishing as Prentice Hall, New Jersey. Edition 14. 2012

21 Website. (n.d.) American Heritage ${ }^{\circledR}$ Dictionary of the English Language, Fifth Edition. (2011). Retrieved January 112017 from http://www.thefreedictionary.com/website

22 Coombs, W. T. (1998). The internet as potential equalizer: New leverage for confronting social irresponsibility. Public Relations Review, 24(3), 289-303.

23 Thakur, R. and Summey, J. H. (2005). An exploratory study of the factors that influence the usage or nonusage of websites. Journal of Website Promotion, 1(2), 79-96.

24 Vaughan, C. J., Farrow, L. I., \& B. J. (2006). Evaluating public web site information: a process and an instrument. Reference Services Review, 34(1), 12-32.

25 Panopoulou, E., Tambouris, E., \& Tarabani, K. (2008). A framework for evaluating web sites of public authorities. Aslib Proceedings, 60(5), 517-546.

26 Nielsen, J. (1997). Loyalty on the web. Alertbox: Current Issues in Web Usability. Retrieved March 30, 2005, from http://www.useit.com/alertbox/9708a.html 
27 Solomon, M. R. (1994). Consumer behavior (2nd ed.). Upper Saddle River, NJ: Allyn and Bacon

28 Oliver, R. L. (1997). Satisfaction: A behavioral perspective on the consumer. Columbus, OH: McGraw-Hill.

29 Elliot, K. M., \& Healy, M. A. (2001). Key factors influencing student satisfaction related to recruitment and retention. Journal of Marketing for Higher Education, 10(4), 1-11.

30 Rindova, V. P. \& Fombrun, C. J. (1999). Constructing competitive advantage: The role of firm-constituent interactions. Strategic Management Journal, 20, 691-710. 